Innovasyon ve Yayıneılık Merkezi
Cypriot Journal of Educational Sciences

Volume 16, Issue 5, (2021) 2609-2620

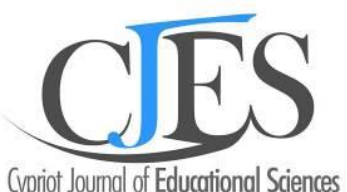

Cypriot Joumal of Educational Sciences

www.cjes.eu

\title{
The human capital from Cebu Technological University: An employment tracer inquiry
}

Lesley Karen B. Penera ${ }^{a}$, Cebu Technological University-Danao Campus, Sabang, Danao City 6004, Cebu, Philippines. les penera@yahoo.com https://orcid.org/0000-0001-5003-0548

Nikkithea L. Beduya ${ }^{\text {b* }}$ Cebu Technological University-Daanbantayan Campus, National, Road, Agujo, Daanbantayan, 6013 Cebu, Philippines. https://orcid.org/0000-0002-9087-2616

Tracy L. Mantos c , Cebu Technological University-Daanbantayan Campus, National Road, Agujo, Daanbantayan, 6013 Cebu, Philippines. https://orcid.org/0000-0002-0745-5169

Iris L. Gulbe ${ }^{d}$, Cebu Technological University-Daanbantayan Campus, National Road, Agujo, Daanbantayan, 6013 Cebu, Philippines.https://orcid.org/0000-0001-5713-4040

\section{Suggested Citation:}

Penera, L.K., T., Beduya, N.L., Mantos, T.L. \& Gulbe, I.L. (2021). The human capital from Cebu Technological University: An employment tracer inquiry. Cypriot Journal of Educational Science. 16(5), 2609-2620 https://doi.org/10.18844/cjes.v16i5.6335

Received from July 19, 2021; revised from August 05, 2021; accepted from october 24, 2021.

C)2021 Birlesik Dunya Yenilik Arastirma ve Yayincilik Merkezi. All rights reserved.

\begin{abstract}
Based on the theory of standardising the academic approach and human capital theory, this study gauged how the respondents from Cebu Technological University-Daanbantayan Campus Graduate School fared in the work arena. It describes the human capital afforded to them by the university, their employment status, the effect of school-related factors on their employment, and the extent of work values and skills' contribution. The researchers utilized the descriptive research design's survey method. Using a validated, modified Graduate Tracer Study instrument, the researchers sourced data from 273 respondents. Findings reveal that majority are employed with permanent status that afforded the country a stable fraction of its workforce - majority of whom is impacting the local area's education industry. Although respondents found that school-related factors moderately affected their employment, the set of work values and skills afforded to them were 'highly contributive'. CTU-Daanbantayan Campus Graduate School has therefore been remarkably instrumental in its graduates and students' employment.
\end{abstract}

Keywords: Graduate tracer study; higher education institutions; human capital; school-related factors; soft skills

* ADDRESS OF CORRESPONCE: Lesley Karen B. Peneraa, Cebu Technological University-Danao Campus, Sabang, Danao City 6004, Cebu, Philippines

Email Address: les_penera@yahoo.com /+63-45-495-6100 


\section{Introduction}

Human capital applies to both the set of skills and the individuals who possess such skill set. The latter bring into play the former at a place of work in order to get the job done and contribute to the development of the workplace. In the Philippines, the human capital is its most critical resource especially when the country morphed into one of the preferred destinations for foreign business outsourcing firms eyeing for educated workers (Global Delivery Initiative, 2020).

The higher education institutions (HEls) in the country function as the hubs for human capital development facilitating the production of highly-qualified manpower. This entails HEls meeting the current labour needs in terms of the relevance of their graduates' qualifications (Mamuli, 2020) particularly when the global work arena has evolved into a highly competitive environment. One wherein technical skill has been rendered insufficient and soft skills became crucial (Dean \& East, 2019). In fact, Cornillez Jr. et al.'s (2021) tracer study on the Teacher Education graduates of Eastern Visayas State University-Tanauan Campus includes findings on communication, human relations, and self-assurance being the most advantageous soft skills in the workplace. The first two [communication and human relations] were likewise reported by Celis, Festijo, and Cueto (2013) to be the most useful competencies afforded by Lyceum of the Philippines to its graduates. It is therefore imperative to continually expose the country's workforce to training and/or education for it to carry on being relevant to the needs of the country's industries thereby significantly impacting the economy's various sectors. This [among others] is what the HEls' graduate education along with their undergraduate programs continues to fulfil. These institutions are seen to ensure education "that meets the standards employers set for their workforce" (Albina \& Sumagaysay, p. 1, 2020). This evidently requires that HEls' academic practices should rise above merely imparting knowledge and developing skills "to ensuring and producing employable graduates" (Albina \& Sumagaysay, p. 2, 2020).

Although a "college degree plays a significant role in determining whether a graduate would land a good job" (Abel, Deitz, \& Finance, 2014 cited in Cuadra, Aure, \& Gonzaga, 2019) the HEls' graduate education became crucial. An undergraduate degree is no longer enough in certain instances either in getting hired or seeking a work promotion when a graduate degree, according to experts, has become a necessity (Martin, 2012). Additionally, apart from the HEls' objective to produce graduates ultimately becoming the country's workforce meeting the industry's needs, HEls are obliged by the Accrediting Agency of Chartered Colleges and Universities in the Philippines (AACCUP), Inc. to comply with the graduate profile documentary requirement as well as by the National Higher Education Research Agenda of the Philippines demanding a regular curriculum program enhancement to maintain the relevance of the competencies required by the industry (Celarta \& Esponilla II, 2021). All these can be satisfied by the Philippine Commission on Higher Education's (CHED) mandate to carry out graduate tracer studies (GTS).

A GTS is a powerful evaluation tool in gauging how well HEls have performed in terms of priming their graduates for the work arena (Cagasan et al., 2017). By investigating their graduates' employment status, HEls are also able to generate valuable information on the university's services, learning environment, facilities (Gines, 2014 cited in Cagasan et al., 2017), curricular offerings, content, and delivery [among others] which may reveal graduates' dissatisfaction (Shongwe \& Ocholla 2011 cited in Cagasan et al., 2017). This information enables HEls to accommodate the demands of the 
actual and potential employers (Canizares, 2015 cited in Albina \& Sumagaysay, 2020) to produce more qualified and competitive graduates thereby improving their employability (Cornillez Jr. et al., 2021).

A GTS by Cagasan et al. (2017) for instance found that majority of their respondents are employed as regular faculty members in academic institutions. These respondents considered the graduate degrees they earned from Visayas State University (VSU) to be highly relevant to their jobs and revealed that communication, human relations, and critical thinking which the graduates acquired from VSU are among the top five skills deemed to be useful in the industry. Nevertheless, Cagasan et al.'s (2017) respondents still suggested rendering VSU's graduate curricular offerings "more responsive to the needs of the students and the employers" (p. 38). Cebu Technological University (CTU), like VSU, offers graduate education. Although Rojas and Rojas' (2016) study on CTU-Main's College of Education ( $\mathrm{CoE}$ ) graduates who were proven proficient and competent to have been employed in government schools is readily available online, the researchers retrieved no literature regarding the state university's graduate education. Therefore, anchored on the prior-mentioned theory of human capital and the theory of standardising the academic approach, this study gauged how the 2015-2019 graduates and students who earned units from various degree programs of CTU Daanbantayan Campus Graduate School fared in the work arena. It likewise described the human capital afforded to them by the state university. Harrison et al. (2015) deemed the theory of standardising the academic approach practical as it "values the importance of stakeholders in making informed decisions" (Celarta \& Esponilla II, p. 49 2021). This GTS thus specifically: 1) ascertained the respondents' employment status; 2) determined the extent of the effect of school-related factors on the respondents' employment; and 3) assessed the extent of the contribution of the work values and skills to the employment of the respondents. Ultimately, it is expected to lay the groundwork for ensuring quality assurance in the state university's graduate school.

\section{Methods and Materials}

\subsection{Research Design}

This study utilized the descriptive design since the researchers, thru its survey method, can only describe and report (Mishra \& Alok, 2011) the employment profile of the respondents, the school-related factors that affected their employment and the extent of contribution of the work values and skills afforded to them by CTU-Daanbantayan Campus Graduate School.

\subsection{Sampling Technique}

CTU-Daanbantayan Campus Graduate School has a record of 483 students from 2015 to 2019 and since only forty (40) of whom are graduates, the researchers opted for the inclusion of those who have earned units in the different graduate degree programs of the state university's graduate school from 2015-2019. Through stratified convenient sampling, 400 were selected as respondents although only 273 or $68 \%$ participated. It nevertheless exceeded by $8 \%$ Schomburg's $30 \%-60 \%$ recommended range for tracer studies (2003).

\subsection{Instrument and Data Collection Technique}


The data-gathering instrument utilized by the researchers was a modified version of the standard Graduate Tracer Study (GTS) developed by the Commission on Higher Education (CHEd) of the Philippines. The modification involved the school-related factors affecting the respondents' employment and the extent of the contribution of work values and skills that were adapted from the literatures of Loretto et al. (2017), Munishi (2016), and Wilton (2012). Rendered as a checklist, the modification constitutes the instrument's last two parts which underwent the obligatory trial run for validation.

The data collection tool has a three-level Likert interval for the factors affecting the graduate's employability. These are described as greatly affecting (2.34-3.00), moderately affecting (1.68-2.33), and less affecting (1.00-1.67); whereas the extent of contribution of the work values and skills provided by CTU Daanbantayan Campus Graduate School to the respondents are categorized as highly contributive (2.34-3.00), contributive (1.68-2.33), and less contributive (1.00-1.67). The study required no identification of reliability and validity issues for there were none.

Data collection involved survey instrument fielded by the researchers, the researchers' colleagues, and other contacts. To maximize the response rate, electronic versions of the instrument were sent thru e-mails and the social media while a small percentage was carried out via the telephone/cellular phone.

Prior to that, the researchers, for ethical consideration, ensured that the respondents understood and signed the consent form thus vouching for their voluntary participation. Moreover, the researchers presented findings in a manner that does not lead to the identification of the respondents thereby protecting their identity.

\subsection{Data Analysis}

Using Microsoft Excel, data were processed, organized, analysed and ultimately summarized in frequency and percentage distribution as well as weighted mean tables. The frequency counts and percentage were used in ascertaining the employment profile of the respondents whereas the weighted mean determined the factors affecting the respondents' employment and the extent of contribution of work values and skills provided by CTU Daanbantayan Campus Graduate School.

\section{Results and Discussion}

This section reveals the employment profile of the respondents, the school-related factors that affected their employment and the extent by which work values and skills bequeathed by CTU Daanbantayan Campus Graduate School to the respondents contributed to their employment.

Table 1 presents the respondents' employment status distribution. Among this inquiry's 273 respondents, 93.41\% (225) are already employed while $6.49 \%$ (18) of them are unemployed. The Philippine Statistics Authority's (PSA) 2019 report however, accounted only for $20.9 \%$ unemployment 
among college graduates, $8.2 \%$ among college freshmen, and $28.2 \%$ among junior high school graduates.

Table 1. Respondents' employment status ( $N=273)$.

Employment Status

Employed

Not employed

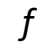

225

18
$\%$

6.49

TOTAL

273

100

Table 2 shows that majority, that is $85.10 \%$ (or 217 out of 255 ) employed respondents have permanent employment status. The remaining few either had contractual, temporary or casual appointments. Four or $1.57 \%$ of the respondents reported being self-employed.

It further reveals that $97.25 \%$ (or 248 out of 273) of these respondents per the 1992 Philippine Standard Occupational Classification (PSOC) are professionals. The rest are clerks, government officials/corporate executives/managers/managing proprietors/supervisors, as well as a plant and machine operator and assembler (Table 2).

The same number of respondents, 248 out of 273 (or $97.25 \%$ ) is employed by the Department of Education (DepEd). That coincides with those in the education industry which is also at $97.25 \%$ while a negligible few are into 'public administration and defense/compulsory social security', 'agriculture and forestry', and the 'hospitality industry' (hotel and restaurants). The remainder are working at CTU, the local government unit (LGU), and the Department of Health (DOH) (Table 2).

These findings suggest that although a few are unemployed when this study was conducted, majority of those who earned graduate school degrees and units from the different programs of CTUDaanbantayan Campus Graduate School have become a stable fraction of the Philippine workforce since most of them are permanently employed. While a few might be impacting the local economic growth thru a few other industries [agriculture and forestry among others], almost all are professionals in the education industry working for DepEd. This further suggests that majority of this country's valuable human resource from CTU-Daanbantayan Campus Graduate School has become a crucial part of human capital development thru basic education. This evidently substantiates Cagasan et al.'s (2017) assertion that graduate education is vital in priming the manpower needed for national development by means of education [and research]. Finally, although VSU Graduate School facilitated in fulfilling the demand for highly-qualified faculty for higher education instruction (Cagasan et al., 2017), evidently, CTU Daanbantayan Campus Graduate School is satisfying the same demand albeit for basic education. 
Table 2. Employed respondents' profile ( $\mathrm{N}=255)$.

\begin{tabular}{|c|c|c|c|c|c|c|c|c|c|c|c|}
\hline $\begin{array}{c}\text { Employment } \\
\text { Status }\end{array}$ & $f$ & $\%$ & Occupation & $f$ & $\%$ & Employer & $f$ & $\%$ & Industry & $f$ & $\%$ \\
\hline Permanent & 217 & 85.10 & $\begin{array}{l}\text { Government } \\
\text { Officials, } \\
\text { Corporate } \\
\text { Executives, } \\
\text { Managers, } \\
\text { Managing } \\
\text { Proprietors } \\
\text { and } \\
\text { Supervisors }\end{array}$ & 3 & 1.18 & DepEd & 248 & 97.25 & $\begin{array}{l}\text { Agriculture } \\
\text { and Forestry }\end{array}$ & 2 & 0.78 \\
\hline Temporary & 14 & 5.49 & Professionals & 248 & 97.25 & $\mathrm{DOH}$ & 1 & 0.39 & $\begin{array}{l}\text { Hotel and } \\
\text { Restaurants } \\
\text { (Hospitality) }\end{array}$ & 2 & 0.78 \\
\hline Contractual & 19 & 7.45 & Clerks & 3 & 1.18 & CTU & 3 & 1.18 & $\begin{array}{l}\text { Public } \\
\text { Administration } \\
\text { and Defense; } \\
\text { Compulsory } \\
\text { Social Security }\end{array}$ & 3 & 1.18 \\
\hline Casual & 1 & 0.39 & $\begin{array}{l}\text { Plant and } \\
\text { Machine } \\
\text { Operators } \\
\text { and } \\
\text { Assemblers }\end{array}$ & 1 & 0.39 & LGU & 3 & 1.18 & Education & 248 & 97.25 \\
\hline $\begin{array}{l}\text { Self- } \\
\text { employed }\end{array}$ & 4 & 1.57 & & & & & & & & & \\
\hline TOTAL & 255 & 100 & & 255 & 100 & & 255 & 100 & & 255 & 100 \\
\hline
\end{tabular}

Note: Occupation is based on the 1992 Philippine Standard Occupational Classification (PISOC).

The school-related factors affecting the respondents' employment in Table 3 reveal that 'School organization skills being matched to objectives of organization to hire or promote' and 'Higher education being matched with undergraduate education, considering the major field of specialization' were both rated with the highest weighted mean of 2.35 interpreted as 'greatly affecting'. This interpretation is shared by 'Subject knowledge and competence on specialization and profession' with a mean of 2.34 while 'Quality of higher education enhancing dropout reduction and boosting prompt program completion' ranked lowest with a mean of 2.15 verbally described as 'moderately affecting'. These factors' average weighted mean is 2.28 interpreted as 'moderately affecting' thereby implying that this study's respondents found that the school-related factors moderately affected their employment. This entails a discussion by academic leaders on how to ensure a $100 \%$ positive employment effect of 'curriculum meeting the predetermined objectives of the employing 
organization'. This can certainly be substantiated by Mamuli's (2020) recommendation for graduates and students [being stakeholders themselves] to contribute towards $\mathrm{HEl}$ curriculum development and/or review to ensure that it conforms to the labour market's current demands. Attention should likewise be afforded to the 'policies and strategies of higher education being implemented toward employability development purposes' and the rest of the school-related factors found to be just 'moderately affecting'

Table 3. Extent of the effect of school-related factors on the respondents' employment $(\mathrm{N}=273)$.

\section{School-Related Factors}

1 Subject knowledge and competence on specialization and profession

2 Subject area being holistic in content in preparation for future employment

3 Subjects' area having a structured training for developing the skills for employability

$4 \quad$ Subjects' area having a structured development program for practical work toward employability

5 Curriculum meeting the predetermined objectives of the employing organization

6 School organization skills being matched to objectives of organization to hire or promote

7 Higher education being matched with undergraduate education, considering the major field of specialization

8 Audit of opportunities being conducted for employability development

9 Policies and strategies of higher education being implemented toward employability development purposes

10 Quality of higher education enhancing dropout reduction and boosting prompt program completion

Average Weighted Mean
Mean Verbal Description

Greatly Affecting

2.32 Moderately Affecting

2.31 Moderately Affecting

2.32 Moderately Affecting

2.28 Moderately Affecting

2.35 Greatly Affecting

$2.35 \quad$ Greatly Affecting

2.21 Moderately Affecting

2.20 Moderately Affecting

2.15 Moderately Affecting

2.28 Moderately Affecting

Legend:

2.34-3.00 Greatly Affecting (GA)

1.68-2.33 Moderately Affecting (MA)

1.00-1.67 Less Affecting (LA) 
As to the extent of contribution, Table 4 shows that all 14 work values provided by CTU Daanbantayan Campus Graduate School to the respondents were 'highly contributive' to their employment with an average weighted mean of 2.67. Loyalty and professionalism ranked first and second with weighted means of 2.76 and 2.74 while self-motivation as well as 'self-respect and respect for others' both ranked third with a 2.72 weighted mean. 'Taking calculated risks' on the other hand, despite being found 'highly contributive' like the rest is ranked the lowest with 2.56 as the weighted mean.

The same table likewise reveals that all 17 work skills afforded by CTU Daanbantayan Campus Graduate School to the respondents were 'highly contributive' to their employment with an average weighted mean of 2.51. Respondents rated 'Communication Skills' 2.59 - the highest weighted mean thereby ranking it first of the 'highly contributive' work skills. This can be corroborated by Celis et al., (2013), Cagasan et al. (2017), and Cornillez Jr. et al.'s (2021) findings which include communication [among others] as the most advantageous soft skill in the workplace.

With the general average weighted mean of 2.59, the respondents believed the work values and work skills bestowed upon them by CTU-Daanbantayan Campus Graduate School to be 'highly contributive' to their employment. This finding implies that the identified work values and work skills afforded to them were certainly crucial in the respondents' field of work. The said work skills include not only hard skills such as one's facility to accomplish the job, but correspondingly involve a number of soft skills such as interpersonal, communication, problem-solving, and teamwork skills. Although the first three along with 'dearth in self-confidence' were found deficient in some studies, (Robles, 2012; Rosenberg, Heimler, \& Morote, 2012; Selvadurai, Choi, \& Maros, 2012 cited in Dean \& East, 2019), these, among others, are the soft skills believed to be imperative in the workplace (Chute, 2012; Ellis, Kisling, \& Hackworth, 2014; Rasul, Rauf, \& Mansor, 2013; Robles, 2012; Wahl et al., 2012 cited in Dean \& East, 2019). The finding, thus further implies that CTU-Daanbantayan Campus Graduate School has been remarkably instrumental in its graduates and students' employment.

Table 4. Extent of contribution of work values and skills provided by CTU-

Daanbantayan Campus to the respondents $(\mathrm{N}=273)$.

\begin{tabular}{llll}
\hline & Aspects of Contribution & Mean & Verbal Description \\
\hline Work Values & & \\
\hline 1 & Strong Work Ethic & 2.66 & Highly Contributive \\
2 & Service and Servant Leadership & 2.62 & Highly Contributive \\
3 & Autonomy, Dependability, and Responsibility & 2.62 & Highly Contributive \\
4 & Positive Attitude & 2.70 & Highly Contributive \\
5 & Adaptability & 2.68 & Highly Contributive \\
6 & Honesty and Integrity & 2.67 & Highly Controbutive \\
7 & Self-Motivated & 2.72 & Highly Contributive \\
8 & Stimulated to Grow and Learn & 2.67 & Highly Contributive
\end{tabular}


$9 \quad$ Strong Self-Confidence

10 Professionalism

11 Self-respect and Respect for Others

Loyalty

Teamwork Tendency

Taking Calculated Risks
2.59

2.74

2.72

2.76

2.64

2.56

2.67
Highly Contributive Highly Contributive Highly Controbutive Highly Contributive Highly Contributive Highly Contributive

Average Weighted Mean

Highly Contributive

\section{Work Skills}

1 Hard Skills, as the general knowledge and relevant skills

Highly Contributive possessed in area of specialization, including manpower awareness on work realities affecting the organization; as computer literacy, others

2 Soft Skills, as the interpersonal skills and attributes needed in the workplace, commonly referred to as professional skills, those that maintain a healthy workplace environment

3 Analytical Skills, as those in confronting a problem, thinking it through, and decisively applying solutions, especially, in current state and conditions of the labor market for job opportunities

4 Investigative Skills in the gathering of information systematically in the establishment of facts and principles in organization work environment

5 Planning, Organizing, Prioritizing Skills on organizational activities and carrying them out effectively

6 Communication Skills, as the ability to express ideas clearly, confidently in writing and speech, with employees, managers, and customers in person, online, in writing, and/or over the phone

7 Interpersonal Skills, also referred to as people skills, used to interact and engage with others and can be developed along with emotional intelligence and selfawareness needed to connect with a hiring team.

8 Leadership Skills, as the successful interacting with employees, colleagues, and customers, toward the achieving of an organization goal

9 Technical Skills, as the experience using industry software, completing higher-level education (college degrees or vocational certifications), or being experienced at highly-specific tasks

10 Transferable Skills, as the employability skills that can be brought from an old position to the new one, as those of communication skills; others

11 License or qualifying examination or certification of

Highly Contributive

2.56 Highly Contributive

Highly Contributive

Highly Contributive

Highly Controbutive

Highly Contributive

Highly Contributive

Highly Contributive

Highly Contributive 
competency/skills in the area of specialization

12 Problem Solving Skills in the analysis of organization work environment issues

13 Time Management Skills in the use of time, prioritizing tasks, and able to meet deadlines

14 Practical Knowledge Skills in handling pragmatic organization work environment challenges

15 Teamwork skills in working confidently with a group

16 Work experience, competence, success gained in the academic, technological ladder on first job/s

17 Inter-work organization employment exchange opportunities

Average Weighted Mean General Average Weighted Mean
2.47

2.56

2.51

2.57

2.52

2.59
Highly Contributive

Highly Contributive

Highly Contributive

Highly Contributive

Highly Contributive

Highly Contributive

Highly Contributive

Highly Contributive

Legend:
2.34-3.00
Highly Contributive (HC)
1.68-2.33 Contributive (C)
1.00-1.67 Less Contributive (LC)

\section{Conclusion and Recommendations}

The findings certainly offer evidence to this inquiry's position that Cebu Technological UniversityDaanbantayan Campus Graduate School bequeathed to its graduates and students a set of 'highly contributive' work values and skills. It has reinforced not only the respondents' hard skills but also the equally important soft skills thereby meeting the local area's [and perhaps the country's] morphing demands for the most vital resource - the human capital that is fundamental to sustainable economic growth. This has afforded the country a fraction of its workforce - majority of whom is impacting the education industry in the local area. Operating as a centre for human resource development along with the country's other higher education institutions, CTU-Daanbantayan Campus Graduate School has therefore been remarkably instrumental in its graduates and students' employment. There is, however, a need for academic leaders to boost the graduates' marketability to ensure zero unemployment and a need to bolster the employment effect of the school-related factors found to be just 'moderately affecting'. Moreover, further study on how graduate degrees fare in terms of work promotion and increased wages may likewise be carried out. Optimistically, this would be executed by adopting an electronic system for the collection, monitoring, retrieval, distribution, repository, and archival of the graduates' employment information thereby creating an online platform for CTUDaanbantayan Campus Graduate School's periodic tracer studies. 
Penera, L.K., T., Beduya, N.L., Mantos, T.L. \& Gulbe, I.L. (2021). The human capital from Cebu Technological University: An employment tracer inquiry. Cypriot Journal of Educational Science. 16(5), 2609-2620 https://doi.org/10.18844/cjes.v16i5.6335

\section{References}

Albina, A.C. \& Sumagaysay, L.P. (2020). Employability tracer study of Information Technology Education graduates from a state university in the Philippines. Social Science and Humanities Open, https://doi.org/10.1016/i.ssaho.2020.100055n .

Cagasan, E., Dargantes, T.M., Florentino, N.N., Lasquites, H. (2017). Tracer study of the graduate degree programs of the Visayas State University. Science and Humanities Journal, 11, 16-39.

Celarta, C.B. \& Esponilla II, F.D. (2021). Industrial education competencies: Valuing students stakeholder's role in the academe. Cypriot Journal of Educational Science. 16(1), 46-56. https://doi.org/10.18844/cjes.v16i1.5507n

Celis, M. I. C., Festijo, B., \& Cueto, A. (2013). Graduate's employability: A tracer study for Bachelor of Science in Hotel and Restaurant Management. Asian Academic Research Journal of Multidisciplinary, 1(11), $225-238$.

Cornillez Jr., E.C., Caminoc, S.R.T., Basa, B.R., Militante Jr., B.T., Paler, R.R., (2021). Tracer study of teacher education graduates of the Eastern Visayas States University-Tanauan Campus, Philippines. European Journal of Education and Pedagogy, 2(3), 2736-4534. DOI : https://doi.org/10.24018/ejedu.2021.2.3.143n

Cuadra, L., Aure, M.R.K., \& Gonzaga, G. (2019). The use of tracer study in improving undergraduate programs in the university. Asia Pacific Higher Education Research Journal. 6(1), 13-25.

Dean, S. \& East, J. (2019). Soft skills needed for the 21st century. International Journal of Applied Management and Technology, 18(1), 17-32. DOI: http://doi.org/10.5590/IJAMT.2019.18.1.02n

Global Delivery Initiative. (2020). Boosting human capital in the Philippines through conditional cash transfers. Washington, DC. (C) World Bank. https://openknowledge.worldbank.org/handle/10986/34211n License: CC BY 3.0 IGO.

Harrison, J. S., Freeman, R. E. \& Sá de Abreu, M. C. (2015). Stakeholder theory as an ethical approach to effective management: applying the theory to multiple contexts. Revista Brasileira de Gestao de Negocios, 17(55), 858-869. doi:10.7819/rbgn.v17i55.2647

Mishra, S.B. \& Alok, S. (2011). Handbook of research methodology. Educreation Publishing.

Loretto, W., Airey, L., \& Yarrow, E. (2017). Older people and employment in Scotland. Social Research series. Retrieved from: https://www.gov.scot/publications/older-people-employment-scotland/documents/

Mamuli, C. (2020). Human capital development and higher education. European Business \& Management, 6(4), 61-66. doi: 10.11648/j.ebm.20200604.11

Martin, D. (2012, June 29). 6 Reasons why graduate school pays off. US News \& World Report. https://www.usnews.com/education/best-graduate-schools/articles/2012/06/29/6-reasons-whygraduate-school-pays-off.

Munishi, EJ. (2016). Factors contributing to lack of employable skills among technical and vocational education (TVET) graduates in Tanzania. Business Education Journal, 1(2):1-19.

Philippines Statistics Authority. (2019). Employment rate in January 2019 is estimated at 94.8 percent. Retrieved from https://psa.gov.ph/content/employmentrate-january-2019-estimated948-percent 
Penera, L.K., T., Beduya, N.L., Mantos, T.L. \& Gulbe, I.L. (2021). The human capital from Cebu Technological University: An employment tracer inquiry. Cypriot Journal of Educational Science. 16(5), 2609-2620 https://doi.org/10.18844/cjes.v16i5.6335

Rojas, T. T., \& Rojas, R. C. (2016). College of education graduate tracer study (GTS): Boon or bane? European Scientific Journal, 12(16), 63-78.

Schomburg, H. (2003). Handbook for graduate tracer studies: centre for research on higher education and work, Kassel, Germany: University of Kassel. Retrieved from http://www.qtafi.de/handbook v2.pdf

Wilton, N. (2012). The impact of work placements on skills development and career outcomes for business and management graduates. Studies in Higher Education, 37(5), 603-620. doi: http://doi./org10.1080/03075079.2010.532548n 